\title{
Foods Commonly Consumed Bychildren From Five African Nations Living In Nigeria
}

\author{
Adeoso, A. Olaitan, Okolie, A. Felix \\ *Lecturer I; Department of Nutrition \& Dietetics, Yaba College of Technology, Yaba, Lagos State; Nigeria.
}

\begin{abstract}
Objective: This study was carried out to evaluate the feeding pattern of children from four African countries residing in Nigeria in relation to that of Nigerian children, the identifying factors that influence their differences in the dietary pattern of the children based on their nationalities and choice of food.
\end{abstract}

\section{Introduction}

African foods is as diverse as the hundreds of cultures and groups that inhabit the continent. This reflects in the feeding pattern from country to country. Children who reside within the borders of their home country usually conform to the feeding pattern of adults, while other children who find their way into country make do with whatever that come their ways due to poverty caused by lack of family and government support.

In East Africa, the Arab influenced their foods while West African meals were influenced by Europeans who invaded our land centuries ago. These foreign foods and our local staples form part of our cuisines and meals.

Food consumption patterns can be defined as the common order or ways of eating foods. Rural residents tend to adhere to their eating patterns instead of changing to a new and more appropriate eating habits (Ogunniyi, 2012). In order to maintain healthful diet, Jama (2002) stated that a variety and balance of foods from all food groups and moderate consumption of all food items is very important.

According to UNICEF, widespread poverty resulting in chronic and persistent hunger is the biggest problem in the developing countries especially in Africa and this has resulted into wasting and stunting of a large children population( UNICEF 2013). Malnutrition is a condition which occurs among large sections of the poor, mainly amongst women and children. In a broader sense, the variable of concern is household's welfare, which is an important component for determining nutritional status. In Nigeria, malnutrition is associated to food shortage linked to both quantity and quality of food to provide a balanced diet (Durojaiye, 1987). Other African countries experience food shortage and ultimately malnutrition also. This rising cases of malnutrition among African children is a major concern for health workers and practitioners and therefore need to be researched in order to bring-up recommendations.

\section{Materials And Methods}

A study was conducted to compare the feeding patterns of Nigerian and children of four other nationalities residing in Nigeria. 120 children between ages 1 and 10 from five different nations (19 Liberians; 27 Sierralonians; 2 Congolese; 2 Rwandans; 70 Nigerians). Convenience sampling method was utilized because it helped in gathering useful data and there were fewer foreign children domiciled in Nigeria willing to participate in the study. The Nigerian children were randomly selected within Surulere Local Government of Lagos State.

A verbal informed consent was sought and obtained from parents, caregivers and community leaders of participants as the case may be. The children of other nationalitieswhose caregivers wanted them were given the questionnaires in the camp and the interviewers assisted them to write and tick the food frequency checklist, demographic characteristics.

The food frequency checklist grouped foods according to similarities in food composition. For example, milk, cheese, and yogurt were grouped under dairy foods; the meat group included fish, chicken, turkey, eggs, groundnut, and dry beans; fresh vegetables were grouped into a vegetable group; citrus fruit or juice, mango, guava, and pawpaw were grouped as fruit; bread, cereals, yam, potato, cassava, rice, and pasta were grouped as grain products.There was a column for specifying other foods not within the group.

Statistical Analysis The study was basically descriptive. Data from each questionnaire were coded and analyzed using the Statistical Package for Social Sciences (SPSS) 16 VERSION. The food consumption frequencies were derived by sorting the responses into two groups of Nigerian and other four countries together. 


\section{Result}

Meal Skipped By Nigerian And Other African Children

\begin{tabular}{|l|l|l|l|l|}
\hline MEAL SKIPPED & NIGERIANS & NON-NIGERIANS & TOTAL & PERCENTAGE \\
\hline Breakfast & 8 & 3 & 11 & $16.9 \%$ \\
\hline Lunch & 10 & 33 & 43 & $66.2 \%$ \\
\hline Dinner & 9 & 2 & 11 & $16.9 \%$ \\
\hline Total & 27 & 38 & 65 & $100 \%$ \\
\hline
\end{tabular}

Food Consumption Of Other African Children

Breakfast

\begin{tabular}{|c|c|c|c|c|c|c|c|}
\hline $\begin{array}{l}\text { Bread \& } \\
\text { Margarine }\end{array}$ & $\begin{array}{l}\text { Rice } \quad \& \\
\text { beans }\end{array}$ & $\begin{array}{l}\text { Rice \& } \\
\text { veg. }\end{array}$ & Pap & $\begin{array}{l}\text { Eba/ Tuwo/solid } \\
\text { meals \& soup }\end{array}$ & $\begin{array}{l}\text { Usually } \\
\text { skipped }\end{array}$ & $\begin{array}{l}\text { Yam } \\
\text { stew }\end{array}$ & $\begin{array}{l}\text { Bean } \\
\text { Pottage }\end{array}$ \\
\hline $\begin{array}{l}26 \\
52 \%\end{array}$ & $\begin{array}{l}3 \\
6 \%\end{array}$ & $\begin{array}{l}5 \\
10 \%\end{array}$ & $\begin{array}{l}5 \\
10 \%\end{array}$ & $\begin{array}{l}1 \\
2 \%\end{array}$ & $\begin{array}{l}3 \\
6 \%\end{array}$ & $\begin{array}{l}5 \\
10 \%\end{array}$ & $\begin{array}{l}2 \\
4 \%\end{array}$ \\
\hline
\end{tabular}

LUNCH

\begin{tabular}{|l|l|l|l|l|l|l|l|}
\hline $\begin{array}{l}\text { Bean } \\
\text { pottage }\end{array}$ & $\begin{array}{l}\text { Rice \& } \\
\text { beans }\end{array}$ & $\begin{array}{l}\text { Rice \& } \\
\text { stew }\end{array}$ & Pap & $\begin{array}{l}\text { Eba/Tuwo/ solid } \\
\text { meals \&soup }\end{array}$ & $\begin{array}{l}\text { Usually } \\
\text { skipped }\end{array}$ & $\begin{array}{l}\text { Bread } \\
\text { stew/tea }\end{array}$ & $\begin{array}{l}\text { Biscuit/ } \\
\text { Pastries }\end{array}$ \\
\hline 3 & 1 & 5 & 2 & 3 & 33 & 1 & 2 \\
$6 \%$ & $2 \%$ & $10 \%$ & $4 \%$ & $6 \%$ & $66 \%$ & $2 \%$ & $4 \%$ \\
\hline
\end{tabular}

SUPPER

\begin{tabular}{|l|l|l|l|l|l|l|l|l|l|}
\hline $\begin{array}{l}\text { Bean } \\
\text { pottage }\end{array}$ & $\begin{array}{l}\text { Rice \& } \\
\text { beans }\end{array}$ & $\begin{array}{l}\text { Rice \& } \\
\text { veg. }\end{array}$ & $\begin{array}{l}\text { Rice \& } \\
\text { stew }\end{array}$ & Yam & $\begin{array}{l}\text { Eba/ starchy solid } \\
\text { meal \& soup }\end{array}$ & $\begin{array}{l}\text { Usually } \\
\text { skipped }\end{array}$ & $\begin{array}{l}\text { Bread \&gg/Stew } \\
\text { Eg }\end{array}$ & $\begin{array}{l}\text { Snack/ } \\
\text { Biscuit }\end{array}$ & $\begin{array}{l}\text { Bread \& } \\
\text { tea }\end{array}$ \\
\hline 2 & 8 & 6 & 20 & 3 & 3 & 3 & 1 & 1 & 3 \\
$4 \%$ & $16 \%$ & $12 \%$ & $40 \%$ & $6 \%$ & $6 \%$ & $6 \%$ & $2 \%$ & $2 \%$ \\
$6 \%$
\end{tabular}

Food Consumption Of Nigerian Children BREAKFAST

\begin{tabular}{|l|l|l|l|l|l|l|l|}
\hline $\begin{array}{l}\text { Yam \& } \\
\text { Egg/ }\end{array}$ & $\begin{array}{l}\text { Bread \& } \\
\text { Tea }\end{array}$ & $\begin{array}{l}\text { Bread } \\
\text { \& stew }\end{array}$ & Pap & $\begin{array}{l}\text { Plantain \& } \\
\text { egg/stew }\end{array}$ & $\begin{array}{l}\text { Usually } \\
\text { skipped }\end{array}$ & $\begin{array}{l}\text { Rice \& } \\
\text { Stew }\end{array}$ & $\begin{array}{l}\text { Noodles/ } \\
\text { Pasta }\end{array}$ \\
\hline 10 & 10 & 17 & 5 & 5 & 8 & 5 & 10 \\
$14.3 \%$ & $14.3 \%$ & $24.3 \%$ & $7.1 \%$ & $7.1 \%$ & $11.4 \%$ & $7.1 \%$ & $14.3 \%$ \\
\hline
\end{tabular}

LUNCH

\begin{tabular}{|l|l|l|l|l|l|l|}
\hline $\begin{array}{l}\text { Beans } \\
\text { yam }\end{array}$ & $\begin{array}{l}\text { Rice \& } \\
\text { beans }\end{array}$ & $\begin{array}{l}\text { Rice \& } \\
\text { stew }\end{array}$ & $\begin{array}{l}\text { Eba/starchy solid } \\
\text { meals\& soup }\end{array}$ & $\begin{array}{l}\text { Usually } \\
\text { skipped }\end{array}$ & $\begin{array}{l}\text { Bread } \\
\text { \&Stew/Egg }\end{array}$ & $\begin{array}{l}\text { Noodles/ } \\
\text { Pasta }\end{array}$ \\
\hline 8 & 7 & 10 & 10 & 10 & 10 & 25 \\
$11.4 \%$ & $10 \%$ & $14.3 \%$ & $14.3 \%$ & $14.3 \%$ & $14.3 \%$ & $35.7 \%$ \\
\hline
\end{tabular}

SUPPER

\begin{tabular}{|l|l|l|l|l|l|l|l|l|}
\hline $\begin{array}{l}\text { Rice \& } \\
\text { beans }\end{array}$ & $\begin{array}{l}\text { Rice \& } \\
\text { stew }\end{array}$ & $\begin{array}{l}\text { Rice \& } \\
\text { veg. }\end{array}$ & $\begin{array}{l}\text { Yam } \\
\text { \& egg }\end{array}$ & $\begin{array}{l}\text { Eba \& } \\
\text { veg. }\end{array}$ & $\begin{array}{l}\text { Usually } \\
\text { skipped }\end{array}$ & $\begin{array}{l}\text { Bread \& } \\
\text { Egg }\end{array}$ & Pottage & $\begin{array}{l}\text { Noodles/ } \\
\text { Pasta }\end{array}$ \\
\hline 5 & 15 & 5 & 10 & 5 & 9 & 8 & 1 & 7 \\
$7.1 \%$ & $21.4 \%$ & $7.1 \%$ & $14.3 \%$ & $7.1 \%$ & $12.9 \%$ & $11.4 \%$ & $1.4 \%$ & $10 \%$ \\
\hline
\end{tabular}

Diertry Pattern Of Nigerians And Non-Nigerians For Breakfast

\begin{tabular}{|l|l|l|l|l|}
\hline NUTRIENTS & NIGERIAN & NON-NIGERIANS & TOTAL & PERCENTAGES \\
\hline Carbohydrate & 15 & 5 & 20 & $18.3 \%$ \\
\hline Protein & 0 & 2 & 2 & $1.8 \%$ \\
\hline Carbohydrate and protein & 32 & 9 & 41 & $37.6 \%$ \\
\hline Carbohydrate and vitamins & 10 & 5 & 15 & $13.8 \%$ \\
\hline Carbohydrate and fat\&oil & 0 & 26 & 26 & $23.9 \%$ \\
\hline Protein and vitamins & 5 & 0 & 5 & $4.6 \%$ \\
\hline Total & 62 & 47 & 109 & $100 \%$ \\
\hline
\end{tabular}

Diertry Pattern Of Nigerians And Non-Nigerians For Breakfast

\begin{tabular}{|l|l|l|l|l|}
\hline NUTRIENTS & NIGERIAN & NON-NIGERIANS & TOTAL & PERCENTAGES \\
\hline Carbohydrate & 25 & 2 & 27 & $32.1 \%$ \\
\hline Protein & 0 & 3 & 3 & $3.6 \%$ \\
\hline Carbohydrate and protein & 45 & 7 & 52 & $61.9 \%$ \\
\hline Fat \& oil & 0 & 2 & 2 & $2.4 \%$ \\
\hline Total & 70 & 14 & 84 & $100 \%$ \\
\hline
\end{tabular}


Diertry Pattern Of Nigerians And Non-Nigerians For Breakfast

\begin{tabular}{|l|l|l|l|l|}
\hline NUTRIENTS & NIGERIAN & NON-NIGERIANS & TOTAL & PERCENTAGES \\
\hline Carbohydrate & 7 & 3 & 10 & $9.7 \%$ \\
\hline Protein & 0 & 2 & 2 & $1.9 \%$ \\
\hline Carbohydrate and protein & 39 & 32 & 71 & $68.9 \%$ \\
\hline Carbohydrate and vitamins & 10 & 9 & 19 & $18.4 \%$ \\
\hline Fat \& oil & 0 & 1 & 1 & $1.1 \%$ \\
\hline Total & 56 & 47 & 103 & $100 \%$ \\
\hline
\end{tabular}

\section{Discussion}

From the food frequencyquestionnaireissued out to participants to assess theirdietarypatterns revealed in breakfast table thatmeals consumed are basically the combination of carbohydrate and protein representing 41 respondents $(37.6 \%)$ where 32 of them are Nigerians and 9 are non-Nigerians, while the least class of food consumed by the respondents as breakfast is protein only consisting of 2 respondents $(1.8 \%)$.

It also shows from the lunch table that the class of food consumed by the respondents are basically the combination of carbohydrate and protein representing 52 respondents $(61.9 \%)$ where 45 of them are Nigerians and 7 are non-Nigerians, while the least class of food consumed by the respondents as breakfast is fat \& oil only consisting of 2 respondents $(2.4 \%)$.

The table for supper shows that the class of food consumed by the respondents are basically the combination of carbohydrate and protein representing 71 respondents $(68.9 \%)$ where 39 of them are Nigerians and 32 are non-Nigerians, while the least class of food consumed by the respondents as breakfast is fat \& oil only consisting of 2 respondents $(1.1 \%)$.

\section{SKIPPED MEALS}

Lunch is the most skipped meal of the day for all the all the respondents consisting of 43 respondents $(66.2 \%)$ where 10 of them are Nigerians and 33 are non-Nigerians. Also, Nigerians skips breakfast and supper than the non-Nigerians.

\section{BREAKFAST}

Bread consumption was common as breakfast meal by both groups.52\% non-Nigerian Children consumed it for breakfast, while $38.6 \%$ Nigerian children consumed bread with either margarine, Tea or stew.

\section{LUNCH}

Rice was often accompanied with beans or stew or vegetables. Noodles and pasta was also common asNigerian Children's meals mostly because of its little preparation time of than 10 minutes. The study also revealed that all participants consumed rice withsoupfour times a week. 85\% consumed tea withbreadfor breakfast. Lessthan one third of the participants consumed thesefoods.All the participants take drinks/sweetened

Eating habits:Most of the respondents (59\%) do notalwaysspread margarine on their bread whiles $16 \%$ always add margarine, $4 \%$ never use margarine and theremaining $21 \%$ never add any spread to their bread. Major reasons given for not using spread were attributedto money. Margarine can be a good source of vitamin A,however trans fatty acids formed during production givesriseto concern. These trans fatty acids increase LDL(harmfulcholesterol) whilst reducing HDL the beneficialcholesterol.This increases the risk of arteriosclerosisand coronary heart disease (George Pamplona, 2006).

It is therefore encouraging to know that most of therespondentsdo not always use margarine. Other spreadsmentioned included groundnut paste and jam.

\section{Conclusion}

Conclusion: Based on the findings of the survey and the discussion being made, the following conclusion could be drawn:

Variability in diet was lacking for most participants.

Consumption of animal protein was low among participants There could be high risk of pernicious anemia among participants due to lack of vitamin B12in their diets Seasonality of fruits determined the kinds of fruits that were consumed Skipping meals was common among all.

Family size was less likely to influence nutritional status of respondents

Adekunle, Julius (2007). Culture and Customs of Rwanda. Greenwood Publishing Group. ISBN 0-313-33177-4. Liberia Comprehensive Food Security and Nutrition Survey (CFSNS) June 2013; 20083439

Comprehensive food security and vulnerability analysis (CFSVA).

Durojaiye BO (1987). Socio-Demographic factors and income distribution in rural Nigeria-the case of AgoIwoye and its implications. The Nig J. of Rural Dev. 1: 15-31. 
Faruk,A., Z. Momtaz, R.K. Moududur, P.B. Cadi, N.H. Mohammed and A.J. Alan, 2000. Dietary pattern, nutrient intake and growth of adolescent school girls in Urban Bangladesh. Retrieved fromhttp://www.journals.cambridge.org/article_S1368980098000159. Accessed on 14th April 2011

GeorgePamplona-Roger, D., 2006. Healthy foods, Editorial Safeliz, Madrid Spain.

Jama PP (2002). A healthy diet. JAMA. 283: 2198-000

journals.cambridge.org/article_S1368980098000 159. Accessed on 14th April, 2011.

Liberia Comprehensive Food Security and Nutrition Survey

Ogunniy LT, Ajao AO, Oladejo JA (2012). Food consumption pattern in Ogbomoso Metropolis of Oyo State Nigeria. JASR, 12 (1): 74-83.

Olumaikaiye, M.F., T. Afinmo and M.A. Olubayo Fatiregun, 2010. Food Consumption Patterns of Nigerian Adolescents and Effect on Body Weight.. Retrieved from www.ncbi.nlm.nih.gov/pudmed/

\section{References}

[1]. Rwandan 2012 National Population Census.

[2]. Sierra Leone (SSL) and ICF Macro. 2009. Sierra Leone Demographic and Health Survey 2008. Calverton. Maryland, USA

[3]. Sierra Leone Multiple indicator Cluster Survey 2005. Final report. Freetown, Sierra Leone: Statistics Sierra Leone and UNICEF

[4]. Statistics Sierra Leone and UNICEF-Sierra Leone. 2007.

[5]. Statistics Sierra Leone. 2004. National Population and Housing census survey

[6]. UNICEF. 2010. The Nutritional Situation in Sierra Leone, Nutrition Survey using SMART Methods 2008

[7]. Wang, Y., L. Jahns, H.L. Tussing, B. Xie, H. Rockette, H. Liang and L. Johnson, 2010. Dietary intake patterns of low-income urban African-American adolescents. Retrieved from http://www.ncbi.nlm.nih.gov/pubmed/ 20800126. Accessed on 17th April, 2011.

[8]. WHO Global Database on Child Growth and Malnutrition-1990

[9]. www.unicef.org/.-IMPROVING CHILD NUTRITION-The achievable imperative for global progress(April 2013) 